\title{
AS DIFICULDADES NA LEITURAE ESCRITA POR CRIANÇAS DA EDUCAÇÃO BÁSICA.
}

\author{
Melissa Maynara dos Passos Rêgo ${ }^{1}$ \\ Valmir Brito de Sousa ${ }^{2}$
}

RESUMO: O projeto circuito de leitura: lendo para ser feliz, em desenvolvimento na E.E.E.F. M Consuelo Coelho e Souza com turmas de $6^{\circ}$ e $7^{\circ}$ ano da educação básica, situado no bairro do 40 Horas apresenta alunos de diferentes faixa etárias e com grandes dificuldades na leitura de literaturas universais. O objetivo desse trabalho é apresentar um relato de experiências com esses alunos inseridos no processo de aceitação e no desenvolvimento tanto da leitura quanto da escrita, pois percebemos o desnivelamento das crianças enquanto ao domínio entre esses dois alicerces da alfabetização. A metodologia do trabalho iniciou em Abriu de 2014 e segue em desenvolvimento. A principio solicitamos as crianças de ambas as turmas a elaboração de redações e posteriormente desenvolvemos com o $6^{\circ}$ ano a leitura do livro "Confissões de um vira- lata” do autor Orígenes Lessa e com o $7^{\circ}$ ano trabalhamos a literatura "Diario de um banana” do autor Jeff Kinney. Apreendemos que o desenvolvimento da segunda turma foi muito maior do que o da primeira, pois essa já havia sido trabalhada no ano anterior e com isso obtivemos uma aceitabilidade tanto da leitura quanto da escrita muito superior ao do $6^{o}$ ano que inicialmente não aceitou o circuito de leitura, pois relutavam em apresentar as suas dificuldades.

PALAVRAS- CHAVE: Leitura. Escrita. Literatura. Dificuldades. Aceitabilidade.

\section{CONTEXTO:}

O projeto circuito de leitura: lendo para ser feliz atua no bairro do 40 horas no município de Ananindeua, na E.E.F.M Consuelo Coelho e Souza, iniciado no mês de abril de 2014 e que hoje encontra-se em pleno desenvolvimento com alunos do $6^{\circ} \mathrm{e}$ $7^{\circ}$ anos da educação básica respectivamente, onde a cada encontro propomos

\footnotetext{
1 Acadêmica de licenciatura em Letras com habilitação em LIBRAS e língua portuguesa como segunda língua da Universidade Federal do Pará- UFPA campus Belém, E-mail: melissamaynara@yahoo.com.br.

2 Acadêmico de licenciatura e bacharelado em Geografia pela Universidade Federal do Pará- UFPA campus Belém, E-mail: valmir13@live.com.pt
} 
diferentes atividades, sejam elas de construções de redações, sejam elas de leituras, enfim há um leque de propostas a serem debatidas juntamente com os alunos.

\section{DESCRIÇÃO DA EXPERIÊNCIA:}

Iniciamos os trabalhos com a solicitação de redações com 30 linhas para a turma do $6^{\circ}$ ano para posteriormente podermos analisar qual era o nível de escrita dessas crianças, à principio os alunos da primeira turma relutou em escrever, pois pedimos muitas linhas escritas e no máximo queriam escrever cinco linhas, a segunda dificuldade era a inventividade do texto além dos erros gramaticais frequentes. No gráfico a baixo apresentamos a porcentagem da aceitabilidade dessas crianças por consequência das dificuldades enfrentadas.

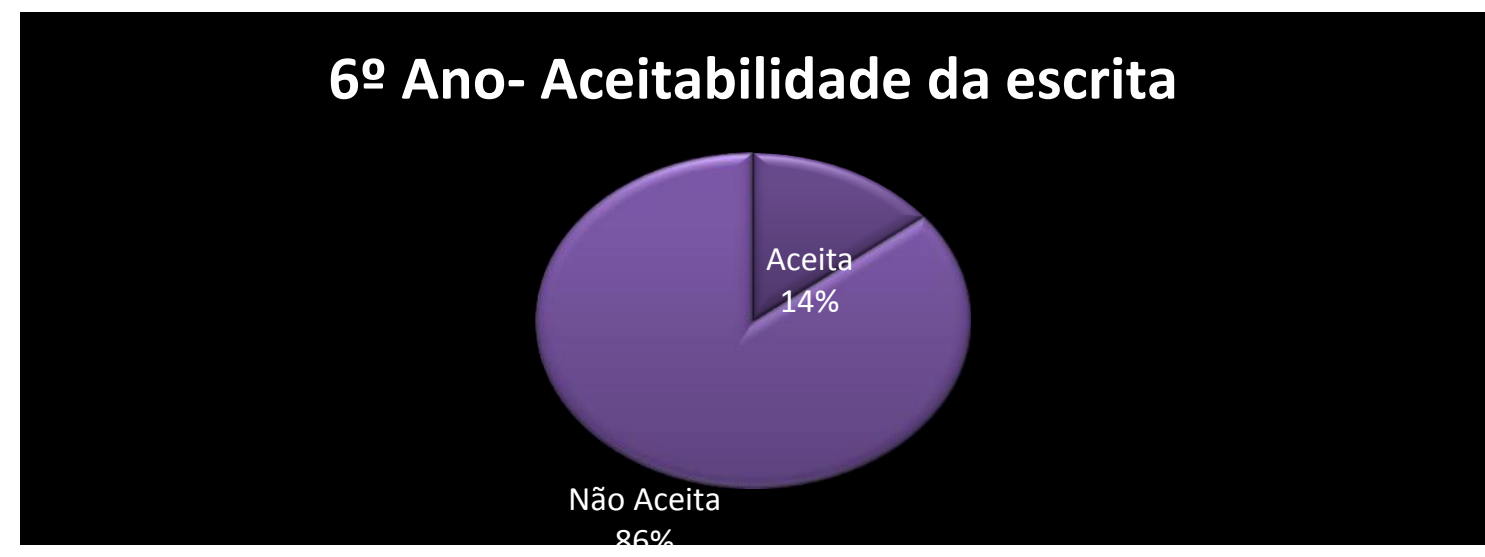

Após trabalharmos os textos escritos iniciamos a leitura do livro "Confissões de um vira-lata" de Orígenes Lessa

\section{Ano- Aceitabilidade da leitura}

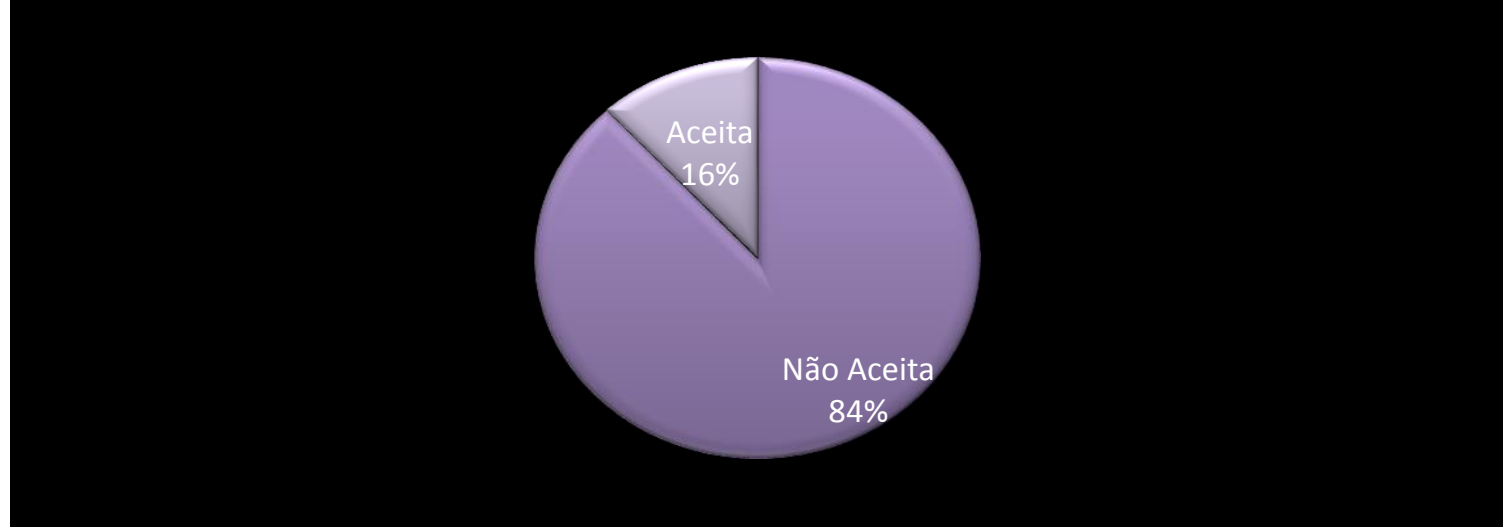


Como podemos perceber no gráfico a cima obtivemos uma aceitação relativamente maior da leitura do que da escrita, no entanto no segundo semestre essa aceitabilidade da leitura aumentou em 50\% com relação ao primeiro semestre, esperamos como resultados futuros dessa turma um desenvolvimento maior na leitura e consequentemente uma performance melhor na escrita, pois pretendemos continuar esse trabalho de leitura e escrita no ano seguinte.

Fazendo um comparativo com a turma do $7^{\circ}$ ano onde realizamos um trabalho similar percebemos que o desenvolvimento era maior do que a turma relatada anteriormente e as dificuldades eram menores, pois com relação a escrita e a leitura a aceitabilidade era muito maior como podemos visualizar no gráfico a seguir:

\section{Ano- Aceitabilidade na Escrita}

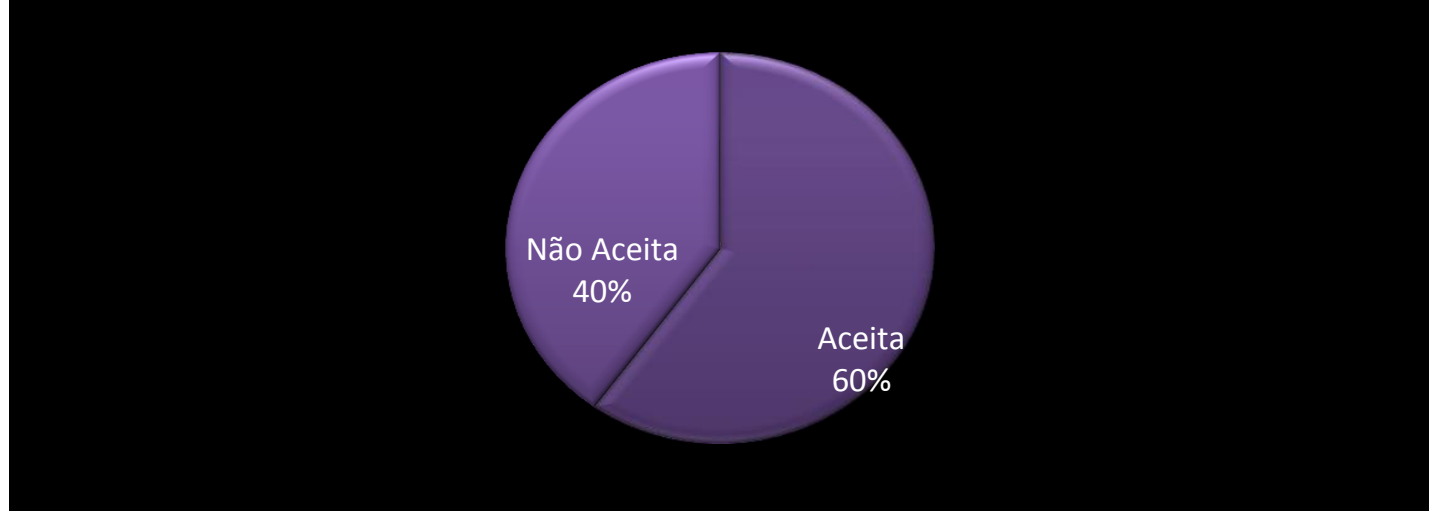

Com relação à leitura, o texto trabalhado foi "Diário de um banana" de Jeff Kinney, os resultados foram ainda mais satisfatórios como podemos ver a seguir:

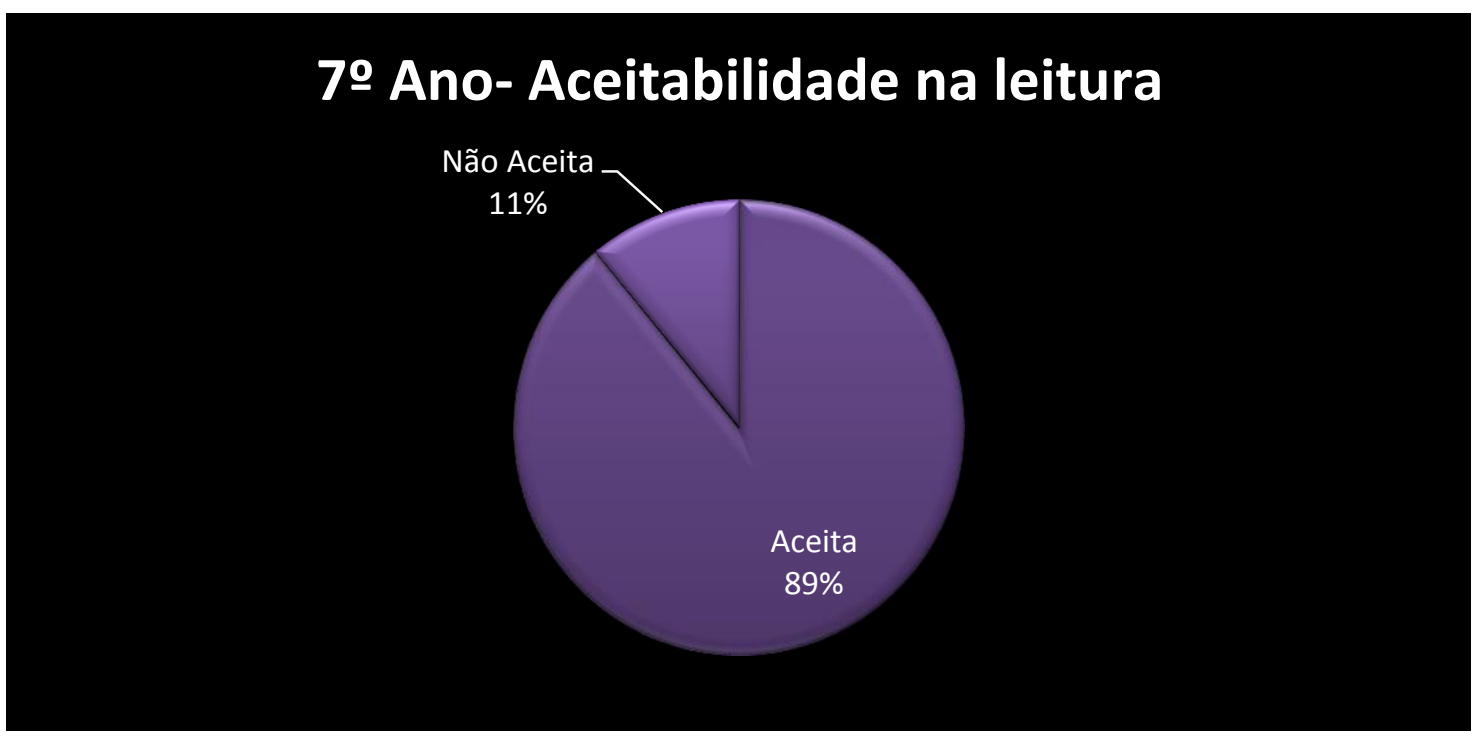

Revista PET Interdisciplinar e Programa Conexões/UFPA On-line. Vol. 01 - 2016. Página 12 


\section{RESULTADOS E CONCLUSÕES:}

Com tudo existe um descompasso entre essas turmas das séries acima citadas, visto que no primeiro contato com a turma do $6^{\circ}$ ano, percebemos o desinteresse deles com o projeto mostrando a realidade por não terem tido um incentivo ainda nos anos iniciais de sua alfabetização, notamos a grande dificuldade em ler e escrever dessses alunos, entretanto com as frequentes investidas conseguimos alcançar um número significativo de crianças interessadas na leitura através da inserção de jornais e posteriormente o livro "confissões de um vira-lata", para assim irem ganhando mais interesse naquilo que almejamos, ou seja, a leitura. No $7^{\circ}$ ano os alunos estão mais acessíveis à prática da leitura, eles conseguem ler muito bem os jornais, elaboram redações mais facilmente do que os do $6^{\circ}$ ano, porém eles têm essa facilidade devido o circuito de leitura já ter no ano anterior trabalhado com esta turma, agora vemos o retorno deles, onde tanto a leitura quanto a escrita são muito boas, isso vem provar o que foi dito anteriormente, a falta de um incentivo em seus anos iniciais de alfabetização, então por meio desses meios buscamos incentivá-los ainda mais, atentando para suas dificuldades, ajudando no que for possível, o projeto circuito de leitura tem esse grande desafio com essas turmas, buscando sempre o prazer pela leitura. Com esse trabalho concluímos que com o desenvolvimento do circuito de leitura as crianças participantes obtiveram um desenvolvimento e aceitabilidade grande em comparação ao inicio do programa tanto da turma já trabalhada quanto da turma que iniciou o circuito esse ano, e com base em FREIRE, 1996, p. 21. "Ensinar não é transferir conhecimento, mas criar as possibilidades para a sua produção ou a sua construção" Assim devemos criar oportunidades de reflexão para esses discentes e com isso teremos desenvolvimento e participação efetiva na sua educação, abrindo assim oportunidades de indagações, sugestões, raciocino e opiniões permitindo que o aluno alcance um real conhecimento a partir da interação social de forma autônoma e prazerosa. 


\section{REFERÊECIAS:}

Concepção da escola ensino e aprendizagem. Disponível em: http://letrasunifacsead.blogspot.com.br/p/paulo-freire-concepcoes-de-escola.html Acesso em 27 set 2014.

FREIRE, Paulo. Pedagogia da autonomia: saberes necessários à prática educativa. São Paulo: Paz e Terra, 1996. (coleção Leitura)

DINIZ, Elloara Azevedo. Construção da leitura e escrita na educação infantil. Disponível em http://castelobrancocientifica.com.br/img.content/artigos/artigo24.pdf Acesso em 27 set 2014. 